Correspondence

Tatyana N. Zhilina zhilinat@mail.ru

\section{Fuchsiella alkaliacetigena gen. nov., sp. nov., an alkaliphilic, lithoautotrophic homoacetogen from a soda lake}

\author{
Tatyana N. Zhilina, ${ }^{1}$ Daria G. Zavarzina, ${ }^{1}$ Angela N. Panteleeva, ${ }^{2}$ \\ Georgy A. Osipov, ${ }^{3}$ Nadezhda A. Kostrikina, ${ }^{1}$ Tatyana P. Tourova ${ }^{1}$ \\ and Georgy A. Zavarzin ${ }^{1}$ \\ ${ }^{1}$ Institute of Microbiology, Russian Academy of Sciences, Prospect 60-letiya Oktyabrya 7/2, \\ Moscow 117312, Russia \\ ${ }^{2}$ Bioengineering Center, Russian Academy of Sciences, Prospect 60-letiya Oktyabrya 7/1, \\ Moscow 117312, Russia \\ ${ }^{3}$ Bakulev Center for Cardiovascular Surgery, Russian Academy of Medical Sciences, \\ Rublevskoe shosse, Moscow 135, Russia
}

\begin{abstract}
The first alkaliphilic obligately anaerobic hydrogenotrophic homoacetogenic bacterium, strain Z-7100 ${ }^{\top}$, was isolated from sediments of the soda-depositing soda lake Tanatar III (Altay, Russia). Cells were thin, flexible rods, motile, Gram-negative and spore-forming. The organism was an obligate alkaliphile, growing at $\mathrm{pH} 8.5$ to 10.5 , with optimum growth at $\mathrm{pH} 8.8-9.3$, and it grew in soda brines containing 1.9-4.7 $\mathrm{M}$ total $\mathrm{Na}^{+}$(optimum at 2.8-3.3 M). It exhibited an obligate dependence upon sodium carbonate but not upon chloride ions with an $\mathrm{NaCl}$ range for growth of $0-14 \%(w / v)$ and an optimum at 7.0-8.5\% (w/v). The isolate was mesophilic and grew at temperatures from 25 to $45{ }^{\circ} \mathrm{C}$, with an optimum at $40{ }^{\circ} \mathrm{C}$. An $\mathrm{H}_{2}+\mathrm{CO}_{2}$ mixture, ethanol, pyruvate and lactate were utilized with the formation of acetate as the sole metabolic product. Carbohydrates and amino acids did not support growth. The isolate had a respiratory type of metabolism, reducing $\mathrm{NO}_{3}^{-}, \mathrm{SeO}_{4}{ }^{2-}$ or anthraquinone-2,6-disulfonate (as electron acceptors with ethanol as an electron donor). It was able to grow chemolithotrophically on $\mathrm{H}_{2}+\mathrm{CO}_{2}$ in medium supplemented with a vitamin solution only. The major cellular fatty acids were the saturated fatty acids anteiso- $C_{15}, C_{14: 0}$ and $C_{16: 0}$ and the aldehydes $C_{16}, C_{14}$ and anteiso- $C_{15}$. The DNA $\mathrm{G}+\mathrm{C}$ content of the isolate was $32.0 \mathrm{~mol} \%$. 16S rRNA gene sequence analysis showed that strain $\mathrm{Z}-7100^{\top}$ is a member of the order Halanaerobiales and represents a new branch within the family Halobacteroidaceae, clustering with the type strain of Selenihalanaerobacter shriftii (92.9\% gene sequence similarity). On the basis of its physiological characteristics and phylogenetic position, the isolate is considered to represent a novel species in a new genus within the family Halobacteroidaceae. The name Fuchsiella alkaliacetigena gen. nov., sp. nov. is proposed. The type strain of the type species is $\mathrm{Z}-7100^{\top}\left(=\mathrm{DSM} 24880^{\top}=\mathrm{VKM} \mathrm{B}-2667^{\top}\right)$.
\end{abstract}

Soda lakes are the end reservoir of subaerial $\mathrm{CO}_{2}$ weathering in semi-arid climates. The process is intrinsically terrestrial and might be regarded as an actualistic model for the reconstruction of the Early Proterozoic terrestrial biosphere (Zavarzin, 1993). Knowledge on the alkaliphilic (or more precisely natronophilic) microbiota of these

Abbreviation: AQDS, anthraquinone-2,6-disulfonate.

The GenBank/EMBL/DDBJ accession number for the 16S rRNA gene sequence of strain Z-7100 ${ }^{\top}$ is $\mathrm{HQ828140.}$

Three supplementary figures are available with the online version of this paper. environments has accumulated mainly over the last two decades (for reviews see Tindall, 1988; Grant et al., 1990; Jones et al., 1998; Zavarzin et al., 1999; Duckworth et al., 1996; Rees et al., 2004; Sorokin \& Kuenen, 2005a, b). The major conclusion from our studies is that the alkaliphilic anaerobic microbial community in soda lakes comprises a complete trophic system limited mainly by total mineralization rather than by high alkalinity and $\mathrm{pH}$ of about 10 (Zhilina \& Zavarzin, 1994; Zavarzin \& Zhilina, 2000; Winogradsky Institute of Microbiology, 2007). The hypothesis of the interrelation between salt tolerance and the efficiency of energy metabolism partially explains the cause of such limitation (Oren, 1999). 
The hydrogen sink in this anaerobic chemotrophic community is controlled by hydrogenotrophic sulfate reducers and sometimes by syntrophic associations (Zhilina et al., 1997, 2005a, b; Pikuta et al., 1998, 2003; Sorokin et al., 2008a, b), whereas methanogens, except for methylotrophs, are mostly repressed by high salinity and therefore substituted by acetogens (Zavarzin et al., 1996, 1999; Zavarzin \& Zhilina, 2000). Among the 22 genera with more than a hundred acetogenic species listed by Drake et al. (2008), representatives of only two genera, namely Natroniella acetigena (Zhilina et al., 1996) and Natronincola histidinovorans (Zhilina et al., 1998), have been isolated from soda lakes. They are however unable to utilize hydrogen. Finding a possible microbial $\mathrm{H}_{2}$ sink in terrestrial ecosystems limited by sulfate (such ecosystems could occur on land in the Early Precambrian period) is of special interest. The aim of our study was to search for hydrogenotrophic alkaliphilic bacteria at $\mathrm{pH}$ around 10 , high alkalinity and salt content close to the precipitation of evaporitic minerals in situ. The Tanatar soda lake group is found on the right bank of the Irtysh River (Altay Region, Russia) in cryo-arid steppe and was chosen as a site for these studies. This site has been a classical field for the investigation of alkaliphilic communities since the 1930s (Issatchenko, 1951). Our search resulted in the isolation of the first alkaliphilic autotrophic $\mathrm{H}_{2}$ consuming bacterium producing acetate as a sole product at $\mathrm{pH} 8.5-10.5$ and total salt content close to that conditioning sodium carbonates precipitation. The isolate is a novel alkaliphilic representative of the order Halanaerobiales. Its physiological properties and phylogenetic position suggest that it represents a novel species in a new genus within family Halobacteroidaceae.

Samples of sediments and water from the Tanatar soda lake group (Altay Region, Russia) were collected by V. V. Kevbrin in June 2008. The samples were collected in screwcapped glass vials without headspace and transported at ambient temperature to the laboratory, where they were stored at $4{ }^{\circ} \mathrm{C}$. The $\mathrm{pH}$ of water at the Tanatar III sampling site was 10.35 and salinity was $10.8 \%$ as measured by refractometer (Carl Zeiss).

The initial enrichment was obtained on an anoxically prepared selective medium containing $\left(\mathrm{g} \mathrm{l}^{-1}\right)$ : $\mathrm{NH}_{4} \mathrm{Cl}, 0.5$; $\mathrm{KH}_{2} \mathrm{PO}_{4}, 0.2 ; \mathrm{MgCl}_{2} .6 \mathrm{H}_{2} \mathrm{O}, 0.1 ; \mathrm{KCl}, 0.2$; yeast extract (Difco), 0.05; $\mathrm{Na}_{2} \mathrm{CO}_{3}, 50.1 ; \mathrm{NaHCO}_{3}, 7.5 ; \mathrm{NaCl}, 47.42$; trace element solution (Kevbrin \& Zavarzin, 1992) $1 \mathrm{ml}$; $\mathrm{Na}_{2} \mathrm{~S} .9 \mathrm{H}_{2} \mathrm{O}, 0.5$ ( $\mathrm{pH}$ 10.16). The medium was dispensed into $120 \mathrm{ml}$ glass flasks with screw caps and the headspace ( $100 \mathrm{ml}$ ) was filled with $\mathrm{H}_{2}$ at atmospheric pressure. Flasks were inoculated with $1 \mathrm{~g}$ sediments (from Lake Tanatar III) and incubated at $35{ }^{\circ} \mathrm{C}$. The composition of the mineral medium for cultivation and maintenance was $\left(\mathrm{g} \mathrm{l}^{-1}\right)$ : $\mathrm{Na}_{2} \mathrm{CO}_{3}, 68 ; \mathrm{NaHCO}_{3}, 38 ; \mathrm{NaCl}, 60$ ( $\mathrm{pH} 9.2$ ); yeast extract (Difco), 0.05 or vitamin solution (Wolin et al., 1963), $10 \mathrm{ml} \mathrm{l}^{-1} ; \mathrm{Na}_{2} \mathrm{~S} .9 \mathrm{H}_{2} \mathrm{O}$, or sodium thioglycollate, 0.5 ; substrates: $\mathrm{H}_{2}(100 \%$ headspace) or ethanol $96 \%(\mathrm{w} / \mathrm{v})$ $5 \mathrm{ml} \mathrm{l}^{-1}$ (corresponding to $87 \mathrm{mM}$ ). No changes were made in the other medium components. Serial dilutions in selective medium with $\mathrm{H}_{2}$ in the gas phase were made and the last positive dilution was used in attempts to isolate colonies in roll-tubes as described previously (Zhilina et al., 1998). However, the organism did not form colonies on agar medium. After repeated tenfold dilutions on medium with yeast extract and vitamins, a pure culture of the novel isolate was obtained and designated strain $\mathrm{Z}-7100^{\mathrm{T}}$. Culture purity was controlled by direct microscopy, negative growth on organic-rich media, and by $16 \mathrm{~S}$ RNA gene sequence analyses.

Phase-contrast photomicrographs and cell size measurements were made by using a Zetopan light microscope (Reichert). Ultrathin sections and electron microscopy of negatively stained cells were performed as described previously (Zhilina et al., 1996). Cells of strain Z-7100 ${ }^{\mathrm{T}}$ were long, thin flexible rods measuring $0.2-0.5 \times 10.0-30.0 \mu \mathrm{m}$. Cells were so flexible that they often folded into hooks or nooses (Fig. 1a). The cells were motile by peritrichous flagella (Fig. 1b). At the late-exponential growth stage, the cells lysed, yielding spheroplasts (see upper arrow in Fig. 1a). Strain Z$7100^{\mathrm{T}}$ formed round endospores (see lower arrow in Fig. 1a). Ultrathin sections revealed cell walls with outer membranes, typical of Gram-negative bacteria (Fig. 1c).

Strain Z $-7100^{\mathrm{T}}$ was an obligate anaerobe and grew only in anoxically prepared media with reductants such as sodium sulfide, cysteine or thioglycollate. In aerobically prepared medium and medium containing 1.5 or $2.0 \% \mathrm{O}_{2}$ no growth occurred. However, the cells were catalase-positive as determined by the formation of $\mathrm{O}_{2}$ bubbles on the cell pellet treated with $3 \%(\mathrm{v} / \mathrm{v}) \mathrm{H}_{2} \mathrm{O}_{2}$ solution. Bacterial growth was monitored by direct cell counting under a phase-contrast microscope and by measuring $\mathrm{OD}_{600}$ (Spectrophotometer2100; UNICO). Quantitative measurements by GC showed that acetate was the sole product. Acetate was assayed by GC Crystall 5000.2 (Russia) equipped with $1 \mathrm{~m}$ glass column filled with the Carbopack C with $0.3 \%$ Carbowax $20 \mathrm{M}$ and $0.1 \% \mathrm{H}_{3} \mathrm{PO}_{4}$ (Supelco) stationary phase. Hydrogen was measured on the same device equipped with $1 \mathrm{~m}$ glass column filled with molecular Sieve SA (Serva).

For substrate utilization tests, the culture was inoculated into mineral medium with yeast extract $\left(0.05 \mathrm{~g} \mathrm{l}^{-1}\right)$. All organic substrates (peptides, carbohydrates, amino acids, alcohols and organic acids) were added to a final concentration of $3 \mathrm{~g} \mathrm{l}^{-1}$ $(\mathrm{w} / \mathrm{v})$ or $3 \mathrm{~g} \mathrm{l}^{-1}(\mathrm{v} / \mathrm{v})$ for alcohols as filter-sterilized $(0.2 \mu \mathrm{m}$; Millipore) concentrated solutions. Medium without substrates and yeast extract $\left(0.05 \mathrm{~g} \mathrm{l}^{-1}\right)$ was used as a control. For growth-positive tests, three subsequent transfers to the same medium were performed. Strain Z- $7100^{\mathrm{T}}$ could only utilize a few substrates. It did not utilize carbohydrates (arabinose, fructose, glucose, galactose, lactose, maltose, mannose, ribose, sucrose, trehalose or xylose). It did not ferment Casamino acids or amino acids used by other homoacetogens (Zhilina et al., 1996, 1998; Zhilina \& Zavarzin, 1990; Kevbrin et al., 1995). It was negative for growth on aspartate, glutamate, histidine, ornithine, methanol, n-propanol, iso-propanol, butanol, mannitol, glycerol, ethylene glycol, 2-3-butanediol, 

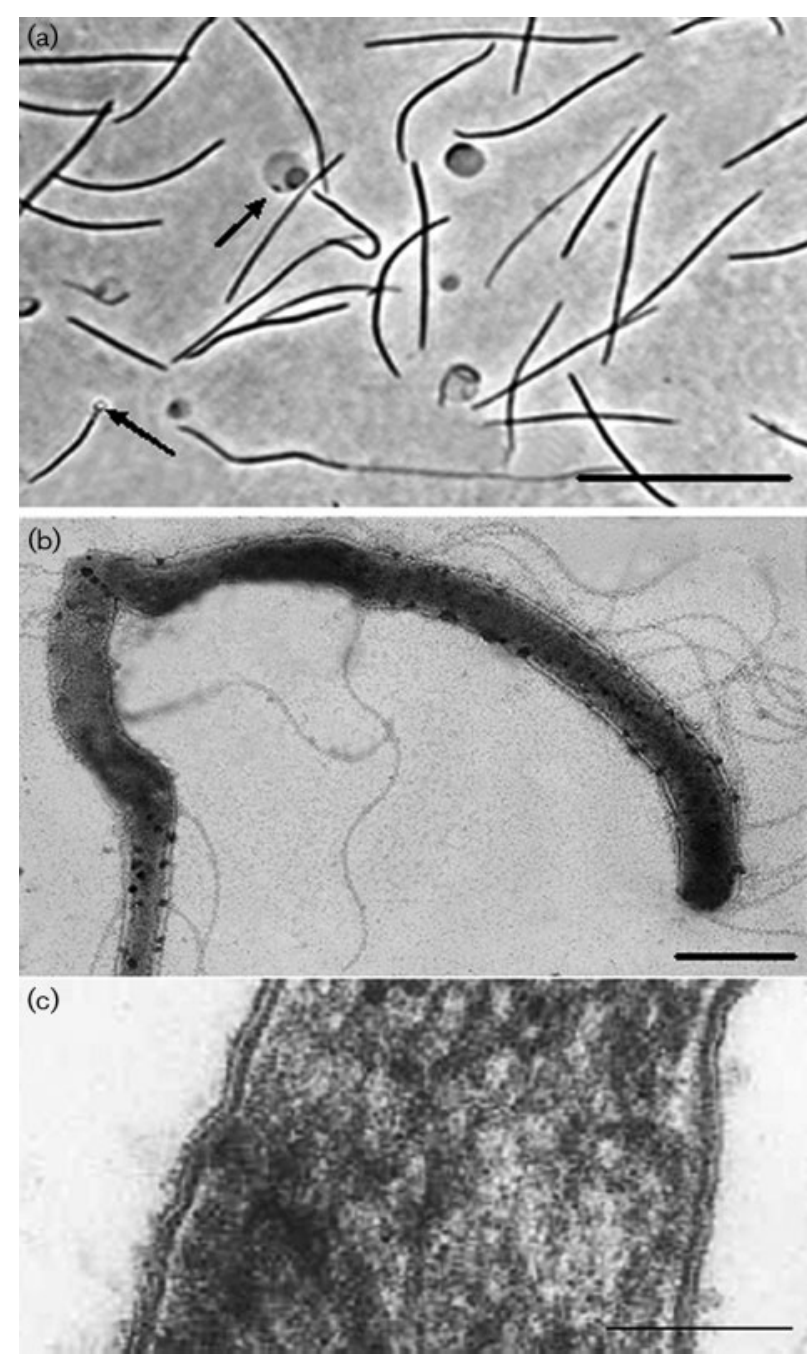

Fig. 1. Morphology of strain $Z-7100^{\top}$. (a) Cells viewed by phasecontrast microscopy (the upper arrow points to a spheroplast, whereas the lower arrow points to an endospore); bar, $10 \mu \mathrm{m}$. (b) Negatively stained flagellated cell; bar, $0.5 \mu \mathrm{m}$. (c) Longitudinal section showing the Gram-negative type structure of the cell wall; bar, $0.1 \mu \mathrm{m}$.

trimethylamine, monomethylamine, formate, succinate, propionate and $N$-acetylglucosamine. Only ethanol, lactate and pyruvate were used by strain $\mathrm{Z}-7100^{\mathrm{T}}$ for chemoorganotrophic growth. In all cases, acetate and $\mathrm{CO}_{2}$ were the only metabolic products of strain $\mathrm{Z}-7100^{\mathrm{T}}$. Traces of $\mathrm{H}_{2}$ were recorded as intermediates during chemo-organotrophic growth. The strain could grow chemolithotrophically with $\mathrm{H}_{2}$ and $\mathrm{CO}_{2}$ without yeast extract, which could be replaced by a vitamin solution (Wolin et al., 1963). For each $4 \mathrm{~mol} \mathrm{H}_{2}$ consumed it produced $1 \mathrm{~mol}$ acetate according to the reaction:

$4 \mathrm{H}_{2}+2 \mathrm{CO}_{2} \rightarrow \mathrm{CH}_{3} \mathrm{COOH}+2 \mathrm{H}_{2} \mathrm{O}$ (see Fig. 2).

Capacity for anaerobic respiration with various acceptors was tested with ethanol as an electron donor. Growth was

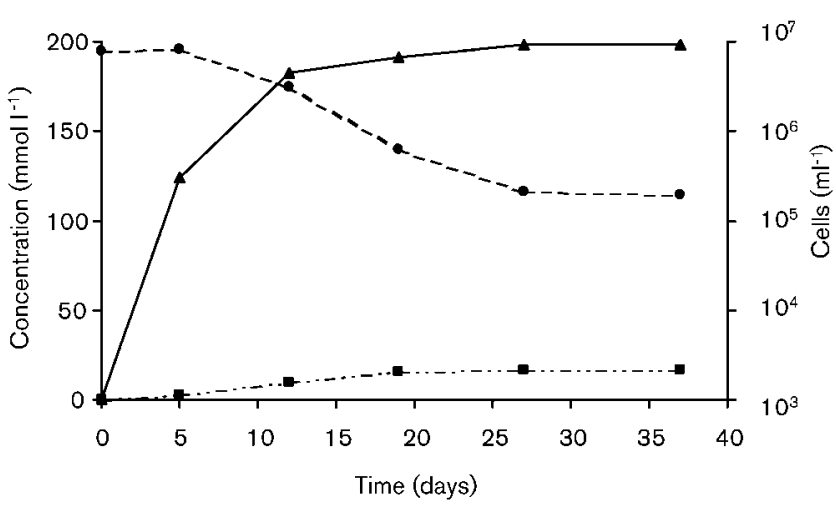

Fig. 2. Growth and acetate production by strain $Z-7100^{\top}$ with hydrogen as an electron donor and $\mathrm{CO}_{2}$ as an electron acceptor. Growth of strain $\mathrm{Z}-7100^{\top}(\mathbf{\Delta})$, acetate production $(\boldsymbol{\square})$ and hydrogen consumption ( $\bullet$ ).

monitored by measuring $\mathrm{OD}_{600}$ and the levels of reduction products were determined as follows: by measuring sulfide (Trüper \& Schlegel, 1964) for sulfur compounds; and iron (II) ferrozine complex at $A_{562}$ (Lovley \& Phillips, 1986) for iron acceptors. Arsenate was detected as described previously (Zavarzina et al., 2009). Selenate and selenite were quantified by ion chromatography with Dionex Ion Pack AS4-ASC $4.6 \times 250 \mathrm{~mm}$ with $2.04 / 2.16 \mathrm{mM}$ bicarbonatecarbonate as eluent. Strain $\mathrm{Z}-7100^{\mathrm{T}}$ reduced $\mathrm{NO}_{3}^{-}(10$ and $20 \mathrm{mM}), \mathrm{SeO}_{4}{ }^{2-}(5 \mathrm{mM})$ and AQDS $(2 \mathrm{mM})$. No growth occurred with $\mathrm{S}_{2} \mathrm{O}_{4}{ }^{2-}(20 \mathrm{mM}), \mathrm{SO}_{3}^{2-}(20 \mathrm{mM}), \mathrm{NO}_{2}^{-}$ $(2 \mathrm{mM})$, iron (III)-EDTA, $\mathrm{S}^{0}(1 \mathrm{w} / \mathrm{v}), \mathrm{AsO}_{4}{ }^{3-}(5 \mathrm{mM})$, $\mathrm{SeO}_{3}{ }^{2-}(2.5 \mathrm{mM})$ or crotonate $(10 \mathrm{mM}$; Sigma $)$. Fumarate (5 mM; Fluka), and $\mathrm{SO}_{4}^{2-}(20 \mathrm{mM})$ did not inhibit growth, but also were not reduced. Only weak reduction of $\mathrm{S}_{2} \mathrm{O}_{3}^{2-}$ was observed. Strain $\mathrm{Z}-7100^{\mathrm{T}}$, with selenate as acceptor and ethanol as donor, completely reduced selenate with formation of an orange-red tint in the medium. The addition of nitrate as an electron acceptor stimulated growth of strain $\mathrm{Z}-7100^{\mathrm{T}}$. Nitrate was reduced to ammonium which was measured by microdiffusion with Nessler reagent. Neither nitrite (Griss reagent after acidification and Merckoquant 1.10020 nitratenitrite tests) nor gaseous nitrogen (GC analysis) were produced. Strain $\mathrm{Z}-7100^{\mathrm{T}}$ did not grow under $100 \%, 30 \%$ or $15 \% \mathrm{CO}$ in the gas phase without acceptors and reaction of $\mathrm{H}_{2}$ formation was not recorded by GC. As inorganic nitrogen sources, the organism used ammonium as well as nitrate and it was incapable of nitrogen fixation. The DNA of strain $\mathrm{Z}-7100^{\mathrm{T}}$ was tested for the presence of nitrogen fixation genes by using universal primers targeting the nifH gene (Marusina et al., 2001), but the gene was not detected.

Vancomycin, novobiocin and rifampicin at $200 \mu \mathrm{g} \mathrm{l}^{-1}$ completely inhibited growth of strain Z-7100 ${ }^{\mathrm{T}}$. Streptomycin, bacitracin and benzylpenicillin at the same concentration did not inhibit growth.

The optimal conditions for growth of strain $\mathrm{Z}-7100^{\mathrm{T}}$ were tested in carbonate-buffered medium with ethanol $(0.5 \%$, 
$\mathrm{w} / \mathrm{v})$ added as the substrate and $\mathrm{NaNO}_{3}(10 \mathrm{mM})$ added as electron acceptor. Growth of strain Z-7100 ${ }^{\mathrm{T}}$ occurred at 25 to $45{ }^{\circ} \mathrm{C}$, with an optimum at $40{ }^{\circ} \mathrm{C}$ (Fig. S1).

The $\mathrm{pH}$ optimum was determined at $37^{\circ} \mathrm{C}$ in the basal medium with $90 \mathrm{~g} \mathrm{NaHCO}_{3} \mathrm{I}^{-1}$ and $70 \mathrm{~g} \mathrm{NaCl} \mathrm{l}^{-1}$. $\mathrm{Na}_{2} \mathrm{CO}_{3}$ was omitted. The $\mathrm{pH}$ value was adjusted by titration of the medium with $12 \mathrm{M} \mathrm{NaOH}$ or $12 \mathrm{M} \mathrm{HCl}$. Strain $\mathrm{Z}-7100^{\mathrm{T}}$ was an obligate alkaliphile. The $\mathrm{pH}$ range for growth was 8.5 to 10.5 with an optimum at $\mathrm{pH} 8.8-9.3$. No growth occurred at $\mathrm{pH}$ lower than 7.6 or higher than 10.6 (Fig. S2).

The $\mathrm{NaCl}$ concentration range suitable for growth was determined in carbonate-buffered basal medium. In situations where the $\mathrm{NaCl}$ concentration was below $60 \mathrm{~g} \mathrm{l}^{-1}$, the total dissolved solids deficiency state was compensated for by adding an equivalent amount of $\mathrm{Na}_{2} \mathrm{SO}_{4}$ (e.g. in the variant with $1 \mathrm{~g} \mathrm{NaCl} \mathrm{l}^{-1}, 59 \mathrm{~g} \mathrm{Na}_{2} \mathrm{SO}_{4} \mathrm{l}^{-1}$ was added). Strain Z-7100 did not require $\mathrm{Cl}^{-}$for growth. However, it was halotolerant and could grow within a $\mathrm{Cl}^{-}$ion concentration range from 0 to $2.5 \mathrm{M}$ with an optimum at 1.2-1.5 $\mathrm{M} \mathrm{Cl}^{-}$.

The dependence of the growth rate upon the total salts content and the salt composition was determined in media containing mixtures of sodium carbonates and chlorides. The basal medium (see above) but with $4.7 \mathrm{M} \mathrm{Na}^{+}$ (3.58 $\mathrm{M} \mathrm{Na}_{2} \mathrm{CO}_{3}, 0.6 \mathrm{M} \mathrm{NaHCO}_{3}$ and $0.5 \mathrm{M} \mathrm{NaCl}$ ) and a saturated solution of carbonates containing $1.75 \mathrm{M} \mathrm{CO}_{3}{ }^{2-}$ and $0.6 \mathrm{M} \mathrm{HCO}_{3}^{-}$were diluted by the basal medium without sodium salts in the following ratio: $1: 9,2: 8,3: 7$, $4: 6,5: 5,6: 4,7: 3,8: 2$ and $9: 1$. Strain Z-7100 ${ }^{\mathrm{T}}$ could grow within the ranges $1.9-4.7 \mathrm{M}$ for $\mathrm{Na}^{+}$and $0.94-$ $2.35 \mathrm{M}$ for $\mathrm{CO}_{3}{ }^{2-}+\mathrm{HCO}_{3}^{-}$. Growth rate was maximal within the ranges $2.8-3.3 \mathrm{M}^{-}$for $\mathrm{Na}^{+}$and $1.41-1.64 \mathrm{M}$ for $\mathrm{CO}_{3}{ }^{2-}+\mathrm{HCO}_{3}^{-}$(Fig. S3). No growth occurred when the organism was inoculated into media with TRIS or CAPS buffers as described previously (Zavarzina et al., 2006) in order to determine the dependence of growth upon sodium carbonates. Strain $\mathrm{Z}-7100^{\mathrm{T}}$ was an obligate and extreme natronophile.

For fatty acid analysis, cells of strain $\mathrm{Z}-7100^{\mathrm{T}}$ were grown on mineral medium with ethanol as the substrate at pH 9.5, $2.75 \mathrm{M} \mathrm{Na}^{+}$and $35{ }^{\circ} \mathrm{C}$ and harvested in the late exponential growth phase. Fatty acid extraction of microorganisms from dry samples $(5 \mathrm{mg}$ ) was carried out by whole biomass acid methanolysis in $0.4 \mathrm{ml} 1.2 \mathrm{M} \mathrm{HCl}$ in methanol by heating to $80^{\circ} \mathrm{C}$ for $1 \mathrm{~h}$. Resulting fatty acid methyl esters were extracted twice with $0.2 \mathrm{ml}$ hexane and processed on an Agilent Technologies AT-5850/5973 GCMS system. The fatty acid profile of strain $\mathrm{Z}-7100^{\mathrm{T}}$ demonstrated that the dominant saturated fatty acids were $\mathrm{C}_{14: 0}(11.39 \%)$, anteiso- $\mathrm{C}_{15}(14.02 \%)$ and $\mathrm{C}_{16: 0}(6.42 \%)$, which constituted about $31.83 \%$ of the total fatty acids. The major aldehydes were $\mathrm{C}_{16}(14.24 \%)$, anteiso- $\mathrm{C}_{15}$ $(6.85 \%)$ and $\mathrm{C}_{14}(7.83 \%)$, which constituted about $28.92 \%$ of the total fatty acids (Table 1 ). Strain Z $-7100^{\mathrm{T}}$ was unique in that it possessed an extraordinary diversity
Table 1. Cellular fatty acid content of strain $Z-7100^{\top}$

Values are percentage $(\mathrm{w} / \mathrm{w})$ of total fatty acids. Major fatty acids are shown in bold. Fatty acids are formatted as follows. For a17:1a, 17 is the number of carbon atoms; the number after the colon denotes the number of double bonds; $a$ or $i$ at the beginning indicates anteiso or iso methyl-branching; a after the numbers indicates aldehyde (e.g. a17:1a represents anteiso-heptadecenoic aldehyde; 16:1 ether represents 1-hexadecenyl ether; i16:1 ether represents iso-1-hexadecenyl ether).

\begin{tabular}{|c|c|}
\hline Fatty acid & Strain Z-7100 \\
\hline $13: 0$ & 0.57 \\
\hline $\mathrm{i} 14$ & 3.32 \\
\hline $14: 1 \omega 5$ & 1.06 \\
\hline $14: 1 \omega 3$ & 1.19 \\
\hline $14: 0$ & 11.39 \\
\hline $12: 03-\mathrm{OH}$ & 0.20 \\
\hline $\mathrm{i} 14 \mathrm{a}$ & 0.81 \\
\hline $14 \mathrm{a}$ & 7.83 \\
\hline i15 & 1.81 \\
\hline a15 & 14.02 \\
\hline a13:0 3-OH & 0.20 \\
\hline i16: 1 ether & 3.74 \\
\hline $15: 0$ & 2.91 \\
\hline i15a & 1.07 \\
\hline a15a & 6.85 \\
\hline $16: 1$ ether & 3.61 \\
\hline $15 \mathrm{a}$ & 4.23 \\
\hline i16 & 0.84 \\
\hline $16: 1 \omega 7$ & 1.87 \\
\hline $16: 0$ & 6.42 \\
\hline i16a & 1.24 \\
\hline $16: 1 \omega 9 \mathrm{a}$ & 0.85 \\
\hline $16: 1 \omega 7 \mathrm{a}$ & 3.63 \\
\hline $16: 1 \omega 5 \mathrm{a}$ & 0.24 \\
\hline $16 \mathrm{a}$ & 14.24 \\
\hline $\mathrm{i} 17$ & 0.20 \\
\hline a17 & 0.37 \\
\hline i17: 1a & 0.60 \\
\hline a17: 1a & 0.31 \\
\hline $\mathrm{i} 17 \mathrm{a}$ & 0.28 \\
\hline a17a & 0.69 \\
\hline $17: 1 \mathrm{a}$ & 0.20 \\
\hline $17 \mathrm{a}$ & 0.28 \\
\hline $18: 1 \omega 9$ & 0.26 \\
\hline $18: 1 \omega 7$ & 0.25 \\
\hline $18: 0$ & 1.13 \\
\hline $18: 1 \mathrm{a} \omega 9$ & 0.54 \\
\hline $18: 1 \mathrm{a} \omega 7$ & 0.19 \\
\hline $18 \mathrm{a}$ & 0.58 \\
\hline$\sum$ & 100 \\
\hline
\end{tabular}

of fatty acids. The identified fatty acids and aldehydes comprise 39 straight and branched species, including hydroxy acids $\mathrm{C}_{12: 0} 3-\mathrm{OH}$ and anteiso- $\mathrm{C}_{13: 0} 3-\mathrm{OH}$ species. The lipid profile alone would suggest that strain $\mathrm{Z}-7100^{\mathrm{T}}$ represents a novel taxon. 


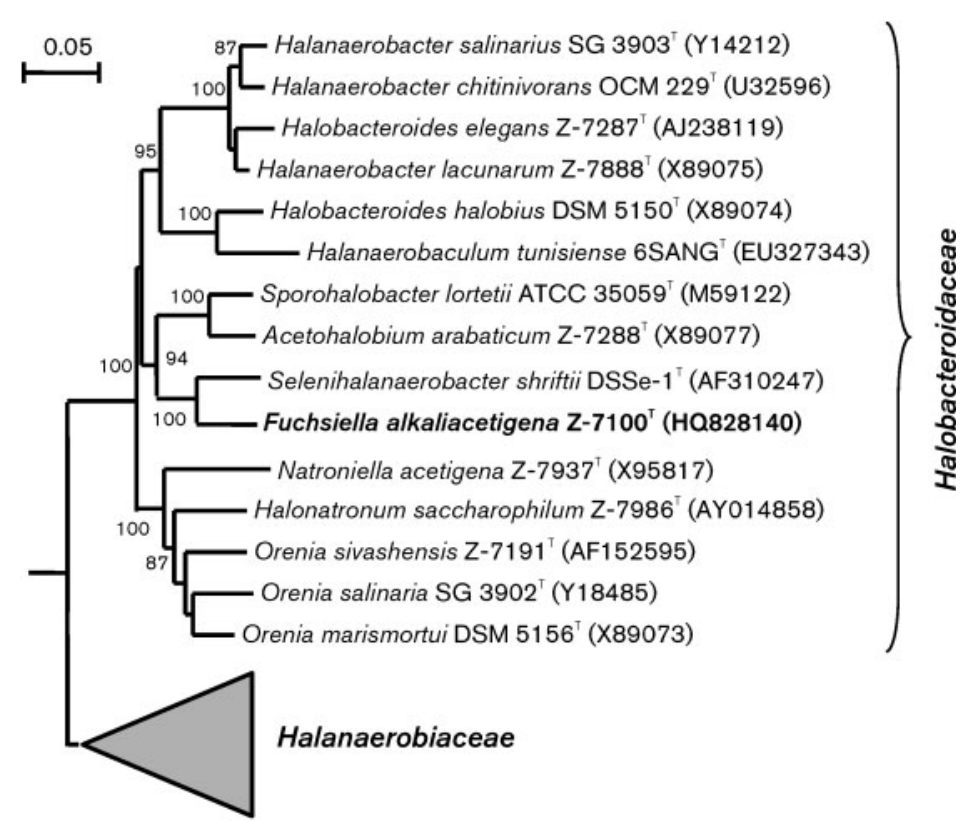

Fig. 3. Neighbour-joining tree with JukesCantor distances based on 16S rRNA gene sequences, showing the position of strain Z$7100^{\top}$ in relation to the closest relatives within the family Halobacteroidaceae. The tree was rooted with the $16 \mathrm{~S}$ rRNA gene sequence of the type strain of Bacillus subtilis as the outgroup. Numbers at nodes are bootstrap values in percentages based on 1000 replicates; only values greater than $70 \%$ are shown. Bar, 5 nt substitutions per 100 nt.
The $\mathrm{G}+\mathrm{C}$ content of the DNA was determined by the thermal denaturation/reassociation technique using a Unicam SP 1800 spectrophotometer (UK) at a rate of $0.5{ }^{\circ} \mathrm{C} \mathrm{min}{ }^{-1}$ and calculated according to Owen et al. (1969). The genomic DNA G $+C$ content of strain Z-7100 ${ }^{\mathrm{T}}$ was $32.0 \pm 0.1 \mathrm{~mol} \%$.

DNA was isolated by a modified Birnboim-Doly alkaline extraction procedure (Birnboim \& Doly, 1979) and according to the Promega Wizard technology. A universal primer system (Lane, 1991) was used to amplify 16S rRNA gene fragments. The amplification products were sequenced by the Sanger method (Sanger et al., 1977) on an ABI PRISM 3730 automatic sequencer (Applied Biosystems) using the Big Dye Terminator v.3.1 kit (Applied Biosystems) according to the manufacturer's instructions. Sequencing was performed in both directions using both external and internal primers. The obtained $16 \mathrm{~S}$ rRNA sequence of strain Z-7100 ${ }^{\mathrm{T}}$ (1486 nt from positions 25 to 1487 in Escherichia coli numbering) was compared with all GenBank entries by a BLAST search (http://www.ncbi.nlm.nih.gov/BLAST), which showed that the closest relatives to the strain were representatives of the family Halobacteroidaceae of the order Halanaerobiales (Rainey et al., 1995; Oren, 2000). These sequences were retrieved and aligned with the sequence of strain Z-7100 ${ }^{\mathrm{T}}$ using the CLUSTAL W (Thompson et al., 1994) algorithm implicated in the BioEdit v.7.0.9.0 software package (Hall, 1999). Phylogenetic trees were reconstructed by using the TREECON software package (Van de Peer \& De Wachter, 1994). Evolutionary distances were calculated by using the Jukes-Cantor algorithm, and the branching order was determined via the neighbour-joining algorithm. The tree in Fig. 3 is a consensus of 1000 replicate trees.

Among species with validly published names, the highest 16S rRNA gene sequence similarity level (92.9\%) was with the type strain of the type species of the genus Selenihalanaerobacter, namely Selenihalanaerobacter shriftii DSSe- $1^{\mathrm{T}}$, which was isolated from the Dead Sea (Switzer Blum et al., 2001). Sequence similarity with other members of this group was in the range 85.9-89.7\%. Sequence similarities with other members of the family Halobacteroidaceae were no more than $92.9 \%$, which corresponds to an intergeneric level within the family of $85.4-95.0 \%$. Thus, it could be concluded that strain $\mathrm{Z}-7100^{\mathrm{T}}$ forms a new line at the genus level within the radiation of the family Halobacteroidaceae.

The novel isolate is a novel alkaliphilic homoacetogenic bacterium in the family Halobacteroidaceae and the first alkaliphilic hydrogenotrophic homoacetogenic bacterium. Strain Z-7100 ${ }^{\mathrm{T}}$ could grow anaerobically by respiratory metabolism and reduced selenate and nitrate, as observed in Selenihalanaerobacter shriftii, or could grow lithotrophically with $\mathrm{H}_{2}+\mathrm{CO}_{2}$ like Acetohalobium arabaticum (Zhilina \& Zavarzin, 1990; Kevbrin et al., 1995). Phenotypic differences between strain $\mathrm{Z}-7100^{\mathrm{T}}$ and its closest phylogenetic relative S. shriftii were significant enough to indicate that the isolate belongs to a new genus. S. shriftii is a neutrophilic moderate halophile, which oxidizes glucose and glycerol to acetate + $\mathrm{CO}_{2}$ with selenate and other electron acceptors, while $\mathrm{Z}-7100^{\mathrm{T}}$ is an alkaliphilic halotolerant natronophile, which can grow lithoautotrophically with molecular hydrogen and does not utilize carbohydrates. Morphologically, strain $\mathrm{Z}-7100^{\mathrm{T}}$ is clearly distinct from $S$. shriftii, the cells of which are non-motile, non-spore-forming straight rods. Natroniella acetigena (Zhilina et al., 1996) is rather close to strain $\mathrm{Z}-7100^{\mathrm{T}}$ phenotypically: it is a natronophilic, homoacetogen able to grow with ethanol, lactate or pyruvate. However it is $\mathrm{Cl}^{-}$-dependent and does not utilize $\mathrm{H}_{2}$ but can use glutamate and propanol. Morphologically, the organisms were clearly distinct and the $16 \mathrm{~S}$ rRNA sequence similarity 
Table 2. Characteristics that differentiate strain $\mathrm{Z}-7100^{\top}$ from homoacetogenic representatives of family Halobacteroidaceae

Strains: 1, Z-7100 ${ }^{\mathrm{T}} ; 2$, Selenihalanaerobacter shriftii DSSe- ${ }^{\mathrm{T}}$ (Switzer Blum et al., 2001); 3, Natroniella acetigena Z-7937 ${ }^{\mathrm{T}}$ (Zhilina et al., 1996); 4, Acetohalobium arabaticum Z-7288 ${ }^{\mathrm{T}}$ (Zhilina \& Zavarzin, 1990; Kevbrin et al., 1995). NR, Not reported.

\begin{tabular}{|c|c|c|c|c|}
\hline Characteristic & 1 & 2 & 3 & 4 \\
\hline \multicolumn{5}{|l|}{ Cell size $(\mu \mathrm{m})$} \\
\hline Width & $0.2-0.3$ & 0.6 & $1.0-1.2$ & $0.7-1.0$ \\
\hline Length & $10.0-30.0$ & $2.0-6.0$ & $6.0-15.0$ & $2.0-5.0$ \\
\hline Motility & + & - & + & + \\
\hline Flexibility & + & - & - & - \\
\hline Spore formation & + & - & + & + \\
\hline \multicolumn{5}{|l|}{ Growth temperature $\left({ }^{\circ} \mathrm{C}\right)$} \\
\hline Range & $25-45$ & $16-42$ & $26-42$ & $\mathrm{NR}-47$ \\
\hline Optimum & 40 & 38 & 37 & $38-40$ \\
\hline \multicolumn{5}{|l|}{ Growth $\mathrm{pH}$} \\
\hline Range & $8.5-10.5$ & $5.3-8.9$ & $8.1-10.7$ & $5.8-8.4$ \\
\hline Optimum & $8.8-9.3$ & 7.2 & $9.7-10.0$ & $7.4-8.0$ \\
\hline \multicolumn{5}{|l|}{$\mathrm{Na}^{+}$total tolerance $(\mathrm{M})$} \\
\hline Range & $1.9-4.7$ & $1.7-4.1$ & $1.7-4.4$ & $1.7-4.3$ \\
\hline Optimum & $2.8-3.3$ & 3.6 & $2.1-2.7$ & $2.7-3.1$ \\
\hline \multicolumn{5}{|l|}{$\mathrm{NaCl}$ tolerance $(\%)$} \\
\hline Range & $0-14$ & $10-24$ & $10-25$ & $10-26$ \\
\hline Optimum & $7.0-8.5$ & 21 & $15-18$ & $12-18$ \\
\hline Dependence on carbonates & + & - & + & - \\
\hline \multicolumn{5}{|l|}{ Utilization of: } \\
\hline Glucose & - & $+^{*}$ & - & - \\
\hline Glutamate & - & - & + & + \\
\hline n-Propanol & - & - & + & - \\
\hline Glycerol & - & $+^{*}$ & - & - \\
\hline Ethanol & + & - & + & - \\
\hline Lactate & + & - & + & + \\
\hline Pyruvate & + & - & + & + \\
\hline Ethanol & + & - & - & + \\
\hline Growth with $\mathrm{H}_{2}+\mathrm{CO}_{2}$ & + & - & - & + \\
\hline DNA G $+\mathrm{C}$ content $(\mathrm{mol} \%)$ & 32.0 & 31.2 & 31.9 & 33.6 \\
\hline Isolation source & Soda Lake Tanatar III, Altay & Dead Sea & Soda Lake Magadi, Kenya & Lake Sivash, Crimea \\
\hline
\end{tabular}

${ }^{\star}$ With electron acceptors.

level between these organisms was low (87.7\%). The features differentiating strain $Z-7100^{\mathrm{T}}$ and its closest phenotypic and phylogenetic relatives among the homoacetogens are summarized in Table 2. On the basis of its physiological properties and phylogenetic analysis, we propose that strain $Z-7100^{\mathrm{T}}$ represents a novel species in a new genus, for which the name Fuchsiella alkaliacetigena gen. nov., sp. nov. is proposed.

\section{Description of Fuchsiella gen. nov.}

Fuchsiella [Fuch.si.el'la. N.L. fem. dim. n. Fuchsiella named in honour of Professor Georg Fuchs (Freiburg, Germany), who made a most serious contribution to our understanding of multiple pathways of $\mathrm{CO}_{2}$ assimilation by micro-organisms].

Gram-negative, spore-forming rods, motile by peritrichous flagella. Obligatory anaerobic. Obligately alkaliphilic and natronophilic. Member of the order Halanaerobiales, family Halobacteroidaceae performing homoacetogenic metabolism of a restricted number of compounds. Able to grow chemolithotrophically with $\mathrm{H}_{2}+\mathrm{CO}_{2}$. Few organic compounds are metabolized with external electron acceptors. Found in soda lakes. The type species is Fuchsiella alkaliacetigena.

\section{Description of Fuchsiella alkaliacetigena sp. nov.}

Fuchsiella alkaliacetigena [al.ka.li.a.ce.ti'ge.na. N.L. n. alkali soda ash; N.L. n. acidum aceticum acetic acid; L. suff. -genus -a -um (from L. v. gigno) producing; N.L. fem. adj. alkaliacetigena producing acetic acid in soda ash].

Cells are thin, long, flexible rods, $0.2-0.5 \times 10.0-30.0 \mu \mathrm{m}$ in size, motile by means of peritrichously located flagella. Cells are so flexible that they often turn into nooses. In the 
late exponential growth phase, the cells lyse, yielding spheroplasts. Spore-forming; spores are round and terminal. The cell wall has a Gram-negative structure.

Obligate anaerobe. Can grow lithoautotrophically on $\mathrm{H}_{2}+$ $\mathrm{CO}_{2}$ or chemo-organotrophically on ethanol, lactate or pyruvate. Vitamin solution can be used as a substitute for yeast extract. Acetate is the sole metabolic product. Capable of respiratory metabolism and can reduce $\mathrm{NO}_{3}^{-}, \mathrm{SeO}_{4}{ }^{2-}$ or AQDS as electron acceptors with ethanol as an electron donor. The dominant cellular fatty acids are $\mathrm{C}_{14: 0}$, anteiso$\mathrm{C}_{15}$ and $\mathrm{C}_{16: 0}$. The major aldehydes are $\mathrm{C}_{16}$, anteiso- $\mathrm{C}_{15}$ and $\mathrm{C}_{14}$. Obligately alkaliphilic with a $\mathrm{pH}$ range for growth of 8.510.7 and an optimum at pH 8.8-9.3. Extremely natronophilic. Carbonates are required for growth. The $\mathrm{Na}^{+}$ concentration range for growth is $1.9-4.7 \mathrm{M}(0.94-2.35 \mathrm{M}$ carbonates) with an optimum at 2.8-3.3 M (1.41-1.64 M carbonates). Halotolerant: the $\mathrm{NaCl}$ concentration range suitable for growth is $0-14 \%(\mathrm{w} / \mathrm{v})$ with an optimum at 7.0$8.5 \% \mathrm{NaCl}(\mathrm{w} / \mathrm{v})$. Mesophilic: the growth temperature range is from 25 to $45{ }^{\circ} \mathrm{C}$, with an optimum at $40{ }^{\circ} \mathrm{C}$. Vancomycin, novobiocin and rifampicin completely inhibit growth.

The type strain, Z-7100 ${ }^{\mathrm{T}}\left(=\right.$ DSM $24880^{\mathrm{T}}=$ VKM B- $\left.2667^{\mathrm{T}}\right)$, was isolated from bottom sediments of soda lake Tanatar III of Kulunda steppe (Altay, Russia). The genomic DNA $\mathrm{G}+\mathrm{C}$ content of the type strain is $32.0 \pm 0.1 \mathrm{~mol} \%$.

\section{Acknowledgements}

This work was supported by the Research program of the Presidium RAS 'The origin of life and evolution of geo-biological systems' and Government contract \#02.740.11.0023. We thank Dr E.N. Detkova for DNA G + C content analysis. We are grateful to Professor A. Oren (Israel) and Professor J. Euzéby (France) for their nomenclature advice for strain $\mathrm{Z}-7100^{\mathrm{T}}$.

\section{References}

Birnboim, H. C. \& Doly, J. (1979). A rapid alkaline extraction procedure for screening recombinant plasmid DNA. Nucleic Acids Res 7, 1513-1523.

Drake, H. L., Gößner, A. S. \& Daniel, S. L. (2008). Old acetogens, new light. Ann N Y Acad Sci 1125, 100-128.

Duckworth, A. W., Grant, W. D., Jones, B. E. \& van Steenbergen, R. (1996). Phylogenetic diversity of soda lake alkaliphiles. FEMS Microbiol Ecol 19, 181-191.

Grant, W. D., Mwatha, W. E. \& Jones, B. E. (1990). Alkaliphiles: ecology, diversity and applications. FEMS Microbiol Rev 75, 255-269.

Hall, T. A. (1999). BioEdit: a user-friendly biological sequence alignment editor and analysis program for Windows 95/98/NT. Nucleic Acids Symp Ser 41, 95-98.

Issatchenko, B. L. (1951). Chloride, sulfate and soda lakes of the Kulundinskaya steppe and the biogenic processes therein. In Izbrannye Trudy (Selected Works of B. L. Issatchenko), pp. 143-162. Moscow: Akad Nauk SSSR.

Jones, B. E., Grant, W. D., Duckworth, A. W. \& Owenson, G. G. (1998). Microbial diversity of soda lakes. Extremophiles 2, 191-200.

Kevbrin, V. V. \& Zavarzin, G. A. (1992). The effect of sulfur compounds on growth of halophilic the homoacetic bacterium
Acetohalobium arabaticum. Microbiology (English translation of Microbiologiia) 61, 563-567.

Kevbrin, V. V., Zhilina, T. N. \& Zavarzin, G. A. (1995). Physiology of homoacetic bacterium Acetohalobium arabaticum. Microbiology (English translation of Microbiologiia) 64, 134-138.

Lane, D. J. (1991). 16S/23S rRNA sequencing. In Nucleic Acid Techniques in Bacterial Systematics, pp. 115-175. Edited by E. Stackebrandt \& M. Goodfellow. Chichester: Wiley.

Lovley, D. R. \& Phillips, E. J. (1986). Availability of ferric iron for microbial reduction in bottom sediments of the freshwater tidal Potomac river. Appl Environ Microbiol 52, 751-757.

Marusina, A. I., Boulygina, E. S., Kuznetsov, B. B., Tourova, T. P., Kravchenko, I. K. \& Gal'chenko, V. F. (2001). A system of oligonucleotide primers for the amplification of nifH genes of different taxonomic groups of prokaryotes. Microbiology (English translation of Microbiologiia) 70, 73-78.

Oren, A. (1999). Bioenergetic aspects of halophilism. Microbiol Mol Biol Rev 63, 334-348.

Oren, A. (2000). The order Halanaerobiales. In The Prokaryotes, 3rd edn, vol. 3, pp. 113-164. Edited by M. Dworkin, S. Falkow, E. Rosenberg, K.-H. Schleifer \& E. Stackebrandt. New York: Springer.

Owen, R. J., Hill, L. R. \& Lapage, S. P. (1969). Determination of DNA base compositions from melting profiles in dilute buffers. Biopolymers 7, 503-516.

Pikuta, E. V., Zhilina, T. N., Zavarzin, G. A., Kostrikina, N. A., Osipov, G. A. \& Rainey, F. A. (1998). Desulfonatronum lacustre gen. nov., sp. nov.: a new alkaliphilic sulfate-reducing bacterium utilizing ethanol. Microbiology (English translation of Microbiologiia) 67, 105-113.

Pikuta, E. V., Hoover, R. B., Bej, A. K., Marsic, D., Whitman, W. B., Cleland, D. \& Krader, P. (2003). Desulfonatronum thiodismutans sp. nov., a novel alkaliphilic, sulfate-reducing bacterium capable of lithoautotrophic growth. Int J Syst Evol Microbiol 53, 1327-1332.

Rainey, F. A., Zhilina, T. N., Boulygina, E. S., Stackebrandt, E., Tourova, T. P. \& Zavarzin, G. A. (1995). The taxonomic status of the fermentative halophilic anaerobic bacteria: description of Haloanaerobiales ord. nov., Halobacteroidaceae fam. nov., Orenia gen. nov., and further taxonomic rearrangements at the genus and species level. Anaerobe 1, 185-199.

Rees, H. C., Grant, W. D., Jones, B. E. \& Heaphy, S. (2004). Diversity of Kenyan soda lake alkaliphiles assessed by molecular methods. Extremophiles 8, 63-71.

Sanger, F., Nicklen, S. \& Coulson, A. R. (1977). DNA sequencing with chain-terminating inhibitors. Proc Natl Acad Sci U S A 74, 5463-5467.

Sorokin, D. Y. \& Kuenen, J. G. (2005a). Haloalkaliphilic sulfuroxidizing bacteria in soda lakes. FEMS Microbiol Rev 29, 685-702.

Sorokin, D. Yu. \& Kuenen, J. G. (2005b). Alkaliphilic chemolithotrophs from soda lakes. FEMS Microbiol Rev 52, 287-295.

Sorokin, D. Yu., Tourova, T. P., Henstra, A. M., Stams, A. J. M., Galinski, E. A. \& Muyzer, G. (2008a). Sulfidogenesis under extremely haloalkaline conditions by Desulfonatronospira thiodismutans gen. nov., sp. nov., and Desulfonatronospira delicata sp. nov. - a novel lineage of Deltaproteobacteria from hypersaline soda lakes. Microbiology 154, 1444-1453.

Sorokin, D. Yu., Tourova, T. P., Mußmann, M. \& Muyzer, G. (2008b). Dethiobacter alkaliphilus gen. nov., sp. nov. and Desulfurivibrio alkaliphilus gen. nov., sp. nov.: two novel representatives of reductive sulfur cycle from soda lakes. Extremophiles 12, 431-439.

Switzer Blum, J. S., Stolz, J. F., Oren, A. \& Oremland, R. S. (2001). Selenihalanaerobacter shriftii gen. nov., sp. nov., a halophilic anaerobe from Dead Sea sediments that respires selenate. Arch Microbiol 175, 208-219. 
Thompson, J. D., Higgins, D. G. \& Gibson, T. J. (1994). CLUSTAL W: improving the sensitivity of progressive multiple sequence alignment through sequence weighting, position-specific gap penalties and weight matrix choice. Nucleic Acids Res 22, 4673-4680.

Tindall, B. J. (1988). Prokaryotic life in the alkaline, saline, athalassic environment. In Halophilic Bacteria, vol. 1, pp. 31-67. Edited by F. Rodriguez-Valera. Boca Raton, FL: CRC Press Inc.

Trüper, H. G. \& Schlegel, H. G. (1964). Sulfur metabolism in Thiorhodaceae. Quantitative measurements on growing cells of Chromatium okenii. Antonie van Leeuwenhoek 30, 225-238.

Van de Peer, Y. \& De Wachter, R. (1994). TREECON for Windows: a software package for the construction and drawing of evolutionary trees for the Microsoft Windows environment. Comput Appl Biosci 10, 569-570.

Winogradsky Institute of Microbiology (2007). Proceedings of the Winogradsky Institute of Microbiology (Winogradsky Institute of Microbiology RAS-Moscow: Nauka, 1951). In Alkaliphilic Microbial Communities, vol. XIV, pp. 396. Edited by V. F. Gal'chenko. Moscow: Nauka (in Russian).

Wolin, E. A., Wolin, M. J. \& Wolfe, R. S. (1963). Formation of methane by bacterial extracts. J Biol Chem 238, 2882-2886.

Zavarzin, G. A. (1993). Epicontinental soda lakes are probable relict biotopes of terrestrial biota formation. Microbiology (English translation of Microbiologiia) 62, 473-479.

Zavarzin, G. A. \& Zhilina, T. N. (2000). Anaerobic chemotrophic alkaliphiles. In Journey to Diverse Microbial Worlds, pp. 191-208. Edited by J. Seckbach. Dordrecht: Kluwer Academic.

Zavarzin, G. A., Zhilina, T. N. \& Pikuta, E. V. (1996). Secondary anaerobes in haloalkaliphilic communities of Tuva Lakes. Microbiology (English translation of Microbiologiia) 65, 480-486.

Zavarzin, G. A., Zhilina, T. N. \& Kevbrin, V. V. (1999). The alkaliphilic microbial community and its functional diversity. Microbiology (English translation of Microbiologiia) 68, 503-521.

Zavarzina, D. G., Kolganova, T. V., Boulygina, E. S., Kostrikina, N. A., Tourova, T. P. \& Zavarzin, G. A. (2006). Geoalkalibacter ferrihydriticus gen. nov., sp. nov., the first alkaliphilic representative of the family
Geobacteraceae, isolated from a soda lake. Microbiology (English translation of Microbiologiia) 78, 673-682.

Zavarzina, D. G., Tourova, T. P., Kolganova, T. V., Boulygina, E. S. \& Zhilina, T. N. (2009). Description of Anaerobacillus alkalilacustre gen. nov., sp. nov. - strictly anaerobic diazotrophic bacillus isolated from soda lake and transfer of Bacillus arseniciselenatis, Bacillus macyae, and Bacillus alkalidiazotrophicus to Anaerobacillus as the new combinations $A$. arseniciselenatis comb. nov., A. macyae comb. nov., and A. alkalidiazotrophicus comb. nov. Microbiology (English translation of Microbiologiia) 78, 723-731.

Zhilina, T. N. \& Zavarzin, G. A. (1990). A new extremely halophilic homoacetogenic bacterium Acetohalobium arabaticum gen. nov., sp. nov. Dokl Akad Nauk SSSR 311, 745-747 (in Russian).

Zhilina, T. N. \& Zavarzin, G. A. (1994). Alkaliphilic anaerobic community at pH10. Curr Microbiol 29, 109-112.

Zhilina, T. N., Zavarzin, G. A., Detkova, E. N. \& Rainey, F. A. (1996). Natroniella acetigena gen. nov., sp. nov., an extremely haloalkaliphilic, homoacetic bacterium: a new member of Haloanaerobiales. Curr Microbiol 32, 320-326.

Zhilina, T. N., Zavarzin, G. A., Rainey, F. A., Pikuta, E. N., Osipov, G. A. \& Kostrikina, N. A. (1997). Desulfonatronovibrio hydrogenovorans gen. nov., sp. nov., an alkaliphilic, sulfate-reducing bacterium. Int J Syst Bacteriol 47, 144-149.

Zhilina, T. N., Detkova, E. N., Rainey, F. A., Osipov, G. A., Lysenko, A. M., Kostrikina, N. A. \& Zavarzin, G. A. (1998). Natronoincola histidinovorans gen. nov., sp. nov., a new alkaliphilic acetogenic anaerobe. Curr Microbiol 37, 177-185.

Zhilina, T. N., Zavarzina, D. G., Kuever, J., Lysenko, A. M. \& Zavarzin, G. A. (2005a). Desulfonatronum cooperativum sp. nov., a novel hydrogenotrophic, alkaliphilic, sulfate-reducing bacterium, from a syntrophic culture growing on acetate. Int J Syst Evol Microbiol 55, 10011006.

Zhilina, T. N., Zavarzina, D. G., Kolganova, T. V., Turova, T. P. \& Zavarzin, G. A. (2005b). "Candidatus Contubernalis alkalaceticum", an obligately syntrophic alkaliphilic bacterium capable of anaerobic acetate oxidation in a coculture with Desulfonatronum cooperativum. Microbiology (English translation of Microbiologiia) 74, 695-703. 